\title{
RATTAN SPECIES AT THREE MOUNTS IN GUNUNG HALIMUN NATIONAL PARK, WEST JAVA
}

\author{
Titi Kalima ${ }^{1}$
}

\section{ABSTRACT}

Management of forest is believed that many basic knowledges about the nature of the forest is needed. One of them is to develop the forest as a resource of cane industry in a sustainable way. For this purpose, the composition, distribution and density of rattan species in Gunung Halimun National Park (TNGH) were studied as a model. Data were collected from December 1994 until May 1995. For species composition on rattan in TNGH, three areas were observed namely in Mt. Kancana, Mt. Pameungpeuk and Mt. Pangkulahan using a continues belt transect method, from the elevation of $800-1,400 \mathrm{~m}$ above sea level. It was found that there were 13 species of rattans in the region. In terms of species richness and densities, Mt. Pameungpeuk comes first, followed by Mt. Pangkulahan and Mt. Kancana. Calamus heteroides, C.javensis, Daemonorops melanochaetes, and Plectocomia elongata are dominant both in seedling and nature forms. The nature rattans are relatively abundant in areas less than 1,000 meter above sea level and decrease in number of species as well as the minimal population in the higher altitude. Calamus ornatus grows well at $800-1,400 \mathrm{~m}$ asl., while Daemonorops ruber at $800-1,500 \mathrm{~m}$ asl., D.oblonga at $800-1,400 \mathrm{~m}$ asl.

Keywords : rattan, species, Gunung Halimun

\section{INTRODUCTION}

Rattan is one of the non-wood forest products, which had sufficient international market. Indonesia export value in 1992 was USD 208,183 . Around $80 \%$ of world rattan supply came from Indonesia. Ninety percent of its quantity were produced from natural forest in Sumatra, Kalimantan, and Sulawesi and around $10 \%$ were extracted from rattan plantation (Sutarno et al., 1994). According to Jacobs (1981) and World Conservation Monitoring Center (1992) the most divers and center of rattan was in Malaysia with the biggest genus of Calamus, Daemonorops and Korthalsia. These plants belong to order of Arecaceae (Uhl and Dransfield, 1987), a climbing plant which grows by its flagellum or cirrus between coppices as a solitary plant or clumps (Rombe, 1986).

More than 600 rattan species were distributed from Africa, India Peninsula, Sri Lanka, South China, Malay Peninsula, Indonesian Archipelago, Papua New Guinea, up to Australia and Fiji Jacobs, 1981; Dransfield et al., 1989, WCMC, 1992). In Indonesia, there were eight genera with more than 300 species (Kramadibrata, 1992) and 28 species of them have important economical value. Two genera with high economical value were Calamus, and Daemonorops (Uhl and Dransfield, 1987 in Dransfield et al., 1989).

A rapid decrease of rattan habitat and the depletion of non-identified species were due to a serious forest destruction in the Gunung Halimun National Park (West Java). Gunung Halimun National Park was the youngest and the largest existing rain forest in Java, therefore it presented high bio-diversity. Among the biodiversity rattan is species which have economic potential (PHPA, 1992). Nevertheless, the amount of population and distribution of each rattan species in the area had been yet widely known.

1 Forest and Nature Conservation Research and Development Center, Bogor 
The knowledge of the density and distribution of rattan population were required, in order to make rattan natural resources can be sustained and utilized optimally. In the effort to conserve the rattan resources in Gunung Halimun National Park, data of rattan population at three mounts in Gunung Halimun National Park, West Java were required. The objectives of research were to collect data about composition of rattan species, population density and distribution of each rattan species in three mounts i.e. Mt. Kancana, Mt. Pameungpeuk and Mt. Pangkulahan.

\section{METHODOLOGY}

\section{A. Study Area}

The observation took place at Mt. Kancana, Mt. Pameungpeuk, and Mt. Pangkulahan in Gunung Halimun National Park area, West Java (Figure 1.). Geographically, the Park area is situated in the latitude of $6^{\circ} 36^{\prime}-6^{\circ} 54^{\prime}$ South and longitude $106^{\circ} 11^{\prime}-106^{\circ} 38^{\prime}$ East. Administratively it belongs to Lebak Regency, and Sukabumi Regency, Bogor Regency, West Java Province.

Topographically, it is hilly and mountainous. Its soil type is between reddish latosol and brown latosol (LPT, 1996). The vegetation consisted of orchid, fern, pandanus, palm, and rattan. Tree species composed of Altingia excelsa, several species of Lauraceae, Fagaceae, and Podocarpaceae.

The monthly average temperature in the research site was $22^{\circ} \mathrm{C}$ and maximum temperature was $27.5^{\circ} \mathrm{C}$ (PT. Nirmala Agung and Cianten, pers comm). The average relative humidity were $82.6 \%$ at noon, $78 \%$ in the afternoon, and annual average rainfall in the north site was $5468 \mathrm{~mm}$ with 245 rain days and at the south side was $4086 \mathrm{~mm}$ annual average rainfall with 211 rain days. The research site is categorized into Af type climate (Koppen), while according to Schmidt and Ferguson (1951), it belongs to A type climate. Research activity was carried out during the period of December 1994 up to May 1995.

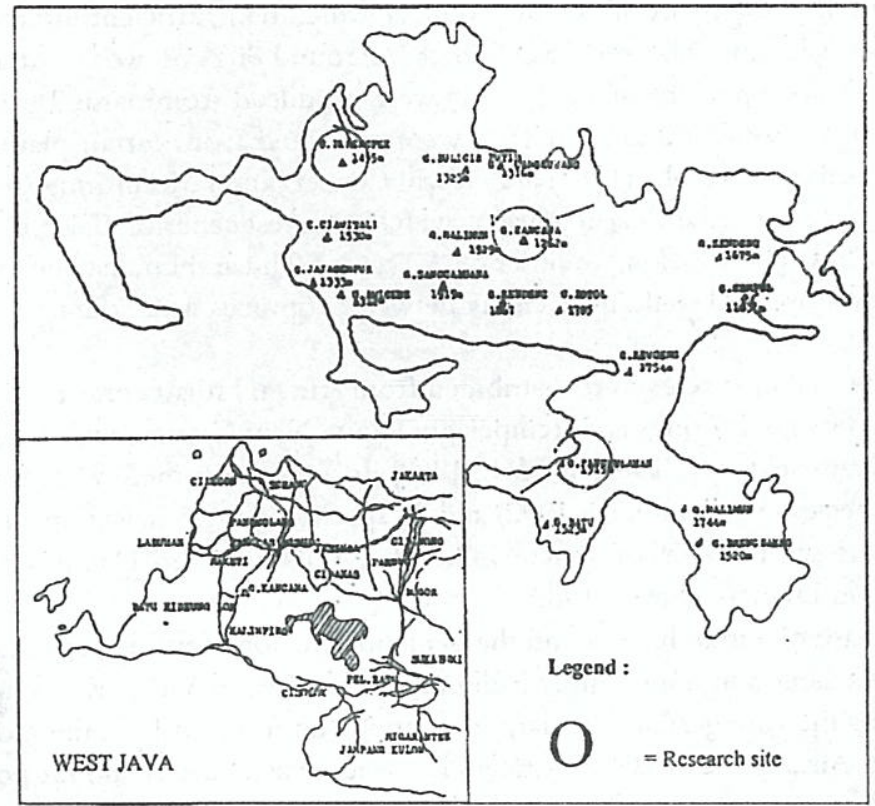

Figure 1. Research location area of rattan species at three mounts in Gunung Halimun National Park, West Java. 


\section{B. Approaches}

Field data collections were done by laying two kilometer length of the transect with quadrate plots plotted along the center of the line. Quadrate plots were laid contiguously along the transect which commonly called as belt transect (Soerianegara and Indrawan, 1988; Kent and Coker, 1992). The rattan observation was taken in each of $20 \times 10 \mathrm{~m}$ seed plots. The density and distribution of rattan species were calculated using Mueller-Dombois and Ellenberg method (1974).

\section{Research Method}

Due to unevenly distribution of rattan species in three mounts of Gunung Halimun National Park, West Java, sample plots for observation were arranged systematically based on rattan coverage. The method used was belt transect/quadrant stripe by combining single plot and line transect. Transect were set up in $2 \mathrm{~km}$ length. This plots size with $20 \mathrm{~m}$ width and $10 \mathrm{~m}$ length. First belt transect was appointed randomly (due to abundance of rattan plants), while the second and next transect were arranged systematically with the distance of $100 \mathrm{~m}$ between each line transect. Line transect was made perpendicular to contour line in some areas with an undulating river or forest road were used as base line to lay down transect in the case of very flat ground. Sample of forest areas were divided into three groups with two kilometer stripe, each stripe consisted of 200 plots, so three were 600 plots in total (Figure 2). Field data collection inventory in Mt. Kancana (800-1210 $\mathrm{m}$ asl.), Mt. Pameungpeuk (850-1210 $\mathrm{m}$ asl.), and Mt. Pangkulahan $(1000-1400 \mathrm{~m}$ asl.). Each area was classified into low sub area $(<1000 \mathrm{~m}$ asl.), and height sub area (>1000 $\mathrm{m}$ asl.).

\section{Rattan Species Inventory}

Species inventory were done in every research plot by using categories recommended by INTAG (1989), Siswanto (1991), and Mogea (personal communication, 1996), i.e. stem length class as follows:

- Seedling, i.e. rattan which stem length $<3 \mathrm{~m}$

- Young rattan, i.e. the stem length of clear rib between 3-5 m

- Adult rattan, i.e. the stem length of clear rib between 5-15 m

- Old rattan, i.e. the stem length of clear $>15 \mathrm{~m}$

Other than those mentioned above, the measurement of stem was also done based on size of diameter: small diameter $(0.5-1.9 \mathrm{~cm})$, medium diameter $(2.0-3.49 \mathrm{~cm})$, big diameter $(3.5$ $-4.9 \mathrm{~cm})$ and super diameter $(>5 \mathrm{~cm})$.

To know the scientific/botanical name at the rattan species and its tree for climbing, identification were done in FNCRDC and in Herbarium Bogorience.

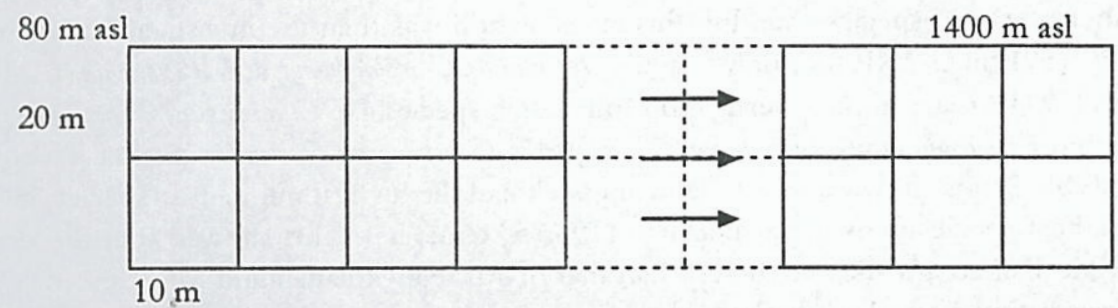

Figure 2. Plots transect position used for inventory of rattan population 


\section{E. Data Analysis}

The resulted data were analyzed by using the following formula:

\section{Density}

2. Relative density (RD)

3. Frequency $(F)$

4. Relative frequency (RF)

5. Important Value Index (IVI) $=\frac{\text { the number of stem or clumps of the species }}{\text { sample area (ha) }}$

$=\frac{\text { the density of one species (ha) }}{\text { the density of all species (ha) }} \times 100 \%$

$=\frac{\text { number of plot where a species was found }}{\text { total number of plots }} \times 100 \%$

\section{RESULT AND DISCUSSION}

\section{A. Rattan Species Composition}

Based on the inventory of rattan species at three mounts in Gunung Halimun National Park (GHNP), there were 13 rattan species, which belong to four Genus. Detailed number of rattan species and genus of each rattan population and its percentage in West Java, were presented in Table 1.

Table 1. The number and percentage of genus, and species in three mounts of Gunung Halimun National Park, West Java.

\begin{tabular}{|l|c|c|c|c|}
\hline Location & $\begin{array}{c}\text { No. of } \\
\text { Genus }\end{array}$ & $\begin{array}{c}\% \text { of } \\
\text { West Java }\end{array}$ & $\begin{array}{c}\text { No. of } \\
\text { Species }\end{array}$ & $\begin{array}{c}\% \text { of } \\
\text { West Java }\end{array}$ \\
\hline Mt. Kencana & 4 & 80 & 8 & 44.4 \\
Mt. Pameungpeuk & 4 & 80 & 13 & 72.2 \\
Mt. Pangkulahan & 4 & 80 & 12 & 66.6 \\
West Java & 5 & 100 & 18 & 100.0 \\
\hline
\end{tabular}

Compared to West Java, rattan in GHNP was represented $80 \%$ of genus consisting of $72.2 \%$ species. The rattan species in GHNP were as follows: Calamus asperrimus Blume, C. ciliaris Blume, C. beteroideus Blume, C. javensis Blume, C. melanoloma Mart., C. ornatus Blume, C. rbomboideus Blume, Daemonorops bystrix Mart., D. melanochaetes Blume, D. oblonga Blume, D. ruber Blume, Korthalsia junghubnii Miq. and Plectocomia elongata Blume.

The number of rattan species found in this investigation was than the investigation result of Istiadi, et al. (1991) in GHNP, they only found C. heteroideus, C. melanoloma, and Plectocomia sp. Mean while Hadi (1994) found in his investigation four rattan species, i.e: $C$. adspersus, C. heterodeus, C. reinwardtii, and $P$. elongata attan species, i.e. : C. adspersus, C. heterodeus, C. reinwardtii, and $P$. elongata.

From Table 2, it is shown that Mt. Pameungpeuk had the highest number of species, it also had the highest species density per hectare (1798.75 stems/ha). This showed that the rattan species in Mt. Pameungpeuk were better than that of Mt. Pangkulahan and Mt. Kancana. The rattan at generation phase had the highest density of the whole research site. The density was 
lower parallel to the increase of stems length class. This happened maybe because of rattan harvesting at large scale by people surrounding forest. The utilization of rattan by local people always happened at every village and almost at every household, especially for household utensils.

Table 2. Mean density of each rattan species (stem/ha) based on length stem class (m) in three sites of Gunung Halimun, National Park

\begin{tabular}{|c|c|c|c|c|c|c|c|c|c|c|c|c|c|c|c|c|}
\hline \multirow{2}{*}{ No } & \multirow[b]{2}{*}{ Species } & \multicolumn{5}{|c|}{ Mount Kancana } & \multicolumn{5}{|c|}{ Mount Pameungpeuk } & \multicolumn{5}{|c|}{ Mount Pangkulahan } \\
\hline & & Seedling & \begin{tabular}{|l|} 
Young \\
Rattan \\
\end{tabular} & \begin{tabular}{|c} 
Adult \\
Rattan \\
\end{tabular} & \begin{tabular}{|c|} 
Old \\
Rattan \\
\end{tabular} & Total & Seedling & \begin{tabular}{|l|} 
Young \\
Rattan \\
\end{tabular} & \begin{tabular}{|c|} 
Adult \\
Rattan \\
\end{tabular} & $\begin{array}{c}\text { Old } \\
\text { Rattan }\end{array}$ & Total & Seedling & \begin{tabular}{|l|} 
Young \\
Rattan \\
\end{tabular} & $\begin{array}{l}\text { Adult } \\
\text { Rattan }\end{array}$ & $\begin{array}{c}\text { Old } \\
\text { Rattan }\end{array}$ & Total \\
\hline 1. & C. het: & 270 & 11.50 & 5.25 & 0.00 & 286.75 & 2.25 & 7.25 & 3.00 & 0.00 & 72 & 07.00 & 3.00 & 0.00 & 0.00 & 707.00 \\
\hline 2. & D. melanochaetes & 168.75 & 4.50 & 6.75 & 0.25 & 180.25 & 135 & 0.75 & 1.50 & 0.0 & 15 & 151.00 & 0.00 & & 0.00 & 151.00 \\
\hline 3. & P. elongata & 106.5 & 3.50 & 4.25 & 0.25 & 4.50 & 6.50 & 2.75 & 2.00 & 0.5 & 5 & 3.00 & 0 & 10 & .00 & 73.00 \\
\hline 4. & D. ruber & 38.5 & 0.50 & 2.75 & 0.50 & 42.25 & 18.50 & 0.25 & 0.25 & 0.0 & 0 & 6.25 & J & 0 & .00 & 26.25 \\
\hline 5. & C. ja & 15.7 & 1 & 0.5 & 0.00 & 17.25 & 534.75 & 16.25 & 38.00 & 1. & 590.25 & 212.50 & 0 & & 0.25 & 213.00 \\
\hline 6. & C. or & 4.7 & 0 & 0.00 & 0.25 & 5.00 & 2.7 & 0.00 & 0.25 & 0.0 & 3. & 8.50 & 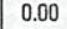 & 0.00 & 0.00 & 8.50 \\
\hline 7. & K. junghuhnï & 0 & 0.25 & 0.25 & 0.00 & 050 & 25.50 & 0.25 & 4.00 & 0.2 & 30.00 & 3.50 & 0 & 0.00 & 0.00 & 3.50 \\
\hline 8. & C. asperrimus & 1 & 0.25 & 1.0 & 0.25 & 250 & 32.50 & 0.00 & 1.00 & 0.2 & 33.75 & 0.50 & 0.00 & 0.00 & 0.00 & 0.50 \\
\hline 9. & C. cillaris & 0 & 0 & 0.00 & 0.00 & 0.00 & 80.25 & 1.50 & 2.50 & 0.0 & 84.25 & 272.00 & 0.00 & 0.00 & 0.00 & 272.00 \\
\hline 10. & D. oblanga & 0 & 0 & 0.00 & 0.00 & 0.00 & 66.00 & 0.50 & 1.00 & 0.0 & 67.50 & 34.25 & 0.00 & 0.00 & 0.00 & 34.25 \\
\hline 11. & D. hystrix & 0 & 0 & 0.00 & 0.00 & 0.00 & 52.50 & 0.25 & 0.25 & 0.0 & 53.00 & 0.00 & 0.00 & 0 & 0.00 & 0.00 \\
\hline 12. & D. rhomboideus & 0 & 0 & 0.00 & 0.00 & 0.00 & 7.50 & 0.00 & 0.75 & 0.0 & 8. & 2.00 & 0.00 & 0.00 & 0.00 & 2.00 \\
\hline 13. & C. melanoloma & 0 & 0 & 0.00 & 0.00 & 0.00 & 2.25 & 1.50 & 3.75 & 0.25 & 7.75 & 2.75 & 0.00 & & 0.00 & 2.75 \\
\hline & Total & 605.25 & 21.50 & 20.75 & 1.50 & 649.00 & 1706.75 & 31.25 & 58,25 & 2.50 & $1 / 98 . / 5$ & 1493.25 & 0.25 & 0.00 & 0.25 & 1493.75 \\
\hline
\end{tabular}

The population density of rattan species at the regeneration phase (stems length $<3 \mathrm{~cm}$ ) of the three-research site was sufficient for the next generation. The density of $C$. beteroideus was the highest either in young rattan phase, adult rattan phase or old rattan phase, i.e $270 \mathrm{stems} / \mathrm{ha}$, 712.25 stems/ha, and 707 stems/ha respectively. This species was almost always existing in every research site, therefore its distribution was the widest. Based on the stem diameter class of the rattan, for the overall density of rattan species in GHNP, the highest density was rattan with small diameter class $(0.5 \mathrm{~cm}-1.9 \mathrm{~cm})$. Drastically, the density of rattan decreased parallel to the increase in stems diameter class as presented in Table 3.

In Table 3, it is shown that Mt. Pangkulahan had the highest rattan species density $(779.75$ stems/ha), but rattan with moderate size (diameter $2 \mathrm{~cm}-3.4 \mathrm{~cm}$ ), big (diameter $3.5 \mathrm{~cm}-4.9 \mathrm{~cm}$ ), and super diameter $(>5 \mathrm{~cm})$. Rattans with super-big diameter were just found in Mt. Kancana, yet it was with very low density, 0.5 stems/ha. The highest rattan species density with moderate and big size was found in Mt. Kancana i.e 16.75 and 5.25 stems/ha respectively. Compared to the rattan species density based on the length stem class, the rattan species density based on stem diameter class was much lower. Such was caused by the fact that most of the rattan species were in regeneration phase, which had stems diameter $<0.5 \mathrm{~cm}$.

The decrease of rattan stems with diameter $>2.0 \mathrm{~cm}$ as found in Mt. Pangkulahan and Mt. Pameungpeuk district, may be related to the rattan harvesting way conducted by local people. They thought that the more frequent they cut the stems, the faster, so that many of the rattan in Mt. Pangkulahan and Mt. Pameungpeuk were stem growth in regeneration phase and further from people residencies. 
Table 3. Mean density of each rattan species (stem/ha) based on stem diameter class in Gunung Halimun National Park

\begin{tabular}{|c|c|c|c|c|c|c|c|c|c|c|c|c|c|c|c|c|}
\hline \multirow{3}{*}{ No } & \multirow{3}{*}{ Species } & \multicolumn{15}{|c|}{ Mean Density } \\
\hline & & \multicolumn{5}{|c|}{ Mount Kancana } & \multicolumn{5}{|c|}{ Mount Pameungpeuk } & \multicolumn{5}{|c|}{ Mount Pangkulahan } \\
\hline & & Small & Medium & Big & Super & Total & Small & Medium & Big & Super & Total & Small & Medium & Big & Super & Total \\
\hline 1. & C. heteroideus & 4.75 & 0.25 & 0.25 & 0.00 & 5.00 & 9.50 & 0.75 & 0 & 0 & 10.25 & 707.00 & 0.00 & 0 & 0 & 487.50 \\
\hline 2. & D. melanochaetes & 4.75 & 0.00 & 0.00 & 0.00 & 4.75 & 54.75 & 0.75 & 0 & 0 & 55.50 & 151.00 & 0.25 & 0.25 & 0 & 74.00 \\
\hline 3. & P. elongata & 4.25 & 4.25 & 4.25 & 0.00 & 8.75 & 2.00 & 0.25 & 0 & 0 & 2.25 & 73.00 & 0.00 & 0 & 0 & 39.75 \\
\hline 4. & D. ruber & 3.75 & 2.00 & 2.00 & 0.00 & 6.00 & 0.25 & 0.25 & 0 & 0 & 0.50 & 26.25 & 0.00 & 0 & 0 & 12.75 \\
\hline 5. & C. javensis & 2.50 & 0.00 & 0.00 & 0.00 & 2.50 & 0.00 & 0.00 & 0 & 0 & 1.25 & 212.50 & 0.00 & 0 & 0 & 0.25 \\
\hline 6. & C. ornatus & 0.75 & 0.00 & 0.00 & 0.00 & 0.75 & 1.75 & 1.75 & 0 & 0 & 4.50 & 8.50 & 0.00 & 0 & 0 & 1.50 \\
\hline 7. & K. junghuinüi & 0.50 & 3.75 & 3.75 & 0.00 & 4.25 & 0.25 & 0.25 & 0 & 0 & 0.25 & 3.50 & 0.00 & 0 & 0 & 4.50 \\
\hline 8. & C. asperrimus & 0.00 & 6.50 & 6.50 & 0.50 & 11.75 & 2.50 & 2.50 & 2 & 2 & 5.25 & 0.50 & 0.00 & 0 & 0 & 73.00 \\
\hline 9. & C. ciliaris & 0.00 & 0.00 & 0.00 & 0.00 & 0.00 & 0.00 & 0.00 & 0 & 0 & 4.00 & 272.00 & 0.00 & 0 & 0 & 57.75 \\
\hline 10. & D. oblanga & 0.00 & 0.00 & 0.00 & 0.00 & 0.00 & 0.25 & 0.25 & 0 & 0 & 1.50 & 34.25 & 0.00 & 0 & 0 & 14.25 \\
\hline 11. & D. hystrix & 0.00 & 0.00 & 0.00 & 0.00 & 0.00 & 0.00 & 0.00 & 0 & 0 & 0.50 & 0.00 & 0.00 & 0 & 0 & 0.00 \\
\hline 12. & C. rhomboideus & 0.00 & 0.00 & 0.00 & 0.00 & 0.00 & 0.00 & 0.00 & 0 & 0 & 0.75 & 2.00 & 0.00 & 0 & 0 & 1.75 \\
\hline \multirow[t]{2}{*}{13.} & C. melanoloma & 0.00 & 0.00 & 0.00 & 0.00 & 0.00 & 0.00 & 0.00 & 0 & 0 & 5.50 & 2.75 & 0.00 & 0 & 0 & 12.75 \\
\hline & Total & 21.25 & 16.75 & 5.25 & 0.50 & 43.75 & 83.25 & 6.75 & 2 & 0 & 92.00 & 779.30 & 0.25 & 0.25 & 0 & 779.80 \\
\hline
\end{tabular}

\section{B. Rattan Distribution Based on Altitude}

Based on the altitude (Table 4), the highest rattan density of the overall species in Mt. Kancana and Mt. Pameungpeuk were found at the altitude $<1000 \mathrm{~m}$ asl, and the density drastically decreased at the altitude of $>1000 \mathrm{~m}$ asl.

The rattan species i.e. C. javensis, C. asperrimus, and $K$. junghubnii, were not found at the altitude $>1000 \mathrm{~m}$ asl in Mt. Kancana. Meanwhile in Mt. Pameungpeuk, C. melanoloma, C. rhomboideus, C. ornatus and $C$. asperrimus were found in small number at the altitude of $>1000 \mathrm{~m}$ asl with the density of $1-2.5 \mathrm{stem} / \mathrm{ha}$. Commonly, in Mt. Pameungpeuk the rattan species that grow at 1000 $\mathrm{m}$ asl, were only $C$. heteroideus, C.ciliaris, $C$. javensis, and $D$. melanochaeies with height density, 151 707 stems/ha and still other species with the density $<100$ stems/ha.

Table 4. Rattan species density per-hectare based in altitude ( $\mathrm{m}$-asl)

\begin{tabular}{|l|l|r|r|r|r|r|}
\hline \multirow{2}{*}{ No } & \multirow{2}{*}{ Species } & \multicolumn{2}{|c|}{ Mount Kancana } & \multicolumn{2}{c|}{ Mount Pameungpeuk } & Mount Pangkulahan \\
\cline { 3 - 7 } & \multicolumn{1}{|c|}{$<1000$} & $<1000$ & $<1000$ & $<1000$ & $<1000$ \\
\hline 1. & C. beteroideus & 266.25 & 22.75 & 687.25 & 135.25 & 707.00 \\
2. & D. melanochaetes & 17.00 & 0.00 & 420.25 & 135.25 & 213.00 \\
3. & P. elongata & 173.50 & 5.00 & 105.50 & 33.50 & 151.00 \\
4. & D. ruber & 5.75 & 18.75 & 35.25 & 6.50 & 73.00 \\
5. & C. javensis & 0.00 & 0.00 & 46.75 & 20.75 & 34.25 \\
6. & C. ornatus & 0.00 & 0.00 & 38.75 & 14.25 & 0.00 \\
7. & K. jungbubnii & 0.00 & 0.00 & 52.00 & 32.25 & 272.00 \\
8. & C. asperrimus & 0.00 & 0.00 & 5.75 & 2.00 & 2.75 \\
9. & C. ciliaris & 0.75 & 0.00 & 19.25 & 10.75 & 3.50 \\
10. & D. oblanga & 39.50 & 2.75 & 14.00 & 5.00 & 2.25 \\
11. & D. bystrix & 0.00 & 0.00 & 6.25 & 2.00 & 2.00 \\
12. & C. rhomboideus & 4.50 & 0.00 & 31.25 & 2.50 & 0.50 \\
13. & C. melanoloma & 2.50 & 0.00 & 2.00 & 1.00 & 8.50 \\
\hline & Total & 599.75 & 49.25 & 1364.25 & 434.50 & 1493.75 \\
\hline
\end{tabular}


In the research site, the rattan were grown at the altitude of $800-1400 \mathrm{~m}$ asl, which belonged to upland zone. This zone was suitable with the zoning system stated by Steenis (1972). At the altitude of $800 \mathrm{~m}-1050 \mathrm{~m}$ asl.as many as 13 rattan species were found i.e. just $C$. rhomboideus and $K$. junghubnii at the altitude of $800 \mathrm{~m}-1050 \mathrm{~m}$ asl. Six other rattan species i.e C. melanoloma, C.ornatus, C. heteroideus, D. oblanga and P. elongata were found at the altitude of $800-1400 \mathrm{~m}$ asl and the rest, $C$ asperrimus, $C$. javensis, $D$. bystrix, $D$. melanochaetes and $D$. ruber at the altitude of $800-1250 \mathrm{~m}$ asl. From the overall rattan species found six species as mentioned revealed the widest distribution (Dransfield, 1974, Madulid, 1981).

Compared to the rattan species distribution pattern stated by to Dransfield (1974), C. melanoloma was mountainous rattan species existing at the altitude of $1500-2000 \mathrm{~m}$ asl. From observation, we know that the rattan distribution of C. melanoloma were grown at the top of the hill, at the altitude of $800-1450 \mathrm{~m}$ asl. This showed that the difference in altitude did not cause problem in the distribution of C. melanoloma, unless the growth conditions were fulfilled or satisfied.

Based on the frequency and density, generally speaking it could be in short that at the altitude of $<1000 \mathrm{~m}$ asl. rattan growth was distributed in high quantity. Meanwhile, at the altitude of $>1000$ asl, the rattan growth distributed in smaller quantity. This revealed that the higher the altitude the less the diversity of rattan species. Futher the diversity of rattan species was determined not only by altitude factor but also by other factors such as physics, soil, and the slope of the three mount area in the GHNP that ranged about 5\% - 88\%. There was a trend that the greater the slope, the less the diversity of plant species. Such could be experiment that the slope could influenced the soil fertility. Result of the research conducted by Pratiwi (1987) and Setiyawati (1995) stated that the soil, nutrient, and organic matter at the steep slope were most vulnerable to the soil erosion. Therefore the steep slope usually had the swallow solum, then becaming less fertile. Meanwhile the soil with gently slope generally was the most ultimate fertile, creating thick solum and hence positively after the rooting system of rattan plants.

Table 5. Importance Value Index (IVI) of rattan species at Mt. Kancana

\begin{tabular}{|c|l|c|c|c|c|}
\hline \multirow{2}{*}{ No } & \multicolumn{1}{|c|}{ Species } & \multicolumn{4}{|c|}{ IVI (\%) } \\
\cline { 3 - 6 } & & Seedling & Young rattan & Adult rattan & Old rattan \\
\hline 1. & C. heteroideus & 75.34 & 74.64 & 38.08 & 0.00 \\
2. & P. elongata & 59.98 & 116.81 & 116.45 & 103.16 \\
3. & D. melanochaetes & 50.14 & 65.10 & 82.01 & 36.69 \\
4. & C. javensis & 4.54 & 15.30 & 21.17 & 0.00 \\
5. & D. ruber & 6.68 & 14.92 & 29.95 & 78.19 \\
6. & C. asperrimus & 0.80 & 8.49 & 9.65 & 30.01 \\
7. & K. junghubnii & 0.00 & 4.83 & 2.67 & 0.00 \\
8. & C. ornatus & 2.42 & 0.00 & 0.01 & 51.95 \\
\hline
\end{tabular}

From Table 5, we saw that in Mt. Kancana the regeneration phase was dominated by $C$. beteroideus (IVI $=75.34 \%$ ), followed in decreasing order by $P$. elongata (IVI $=59.98 \%), D$. melanochaetes (IVI $=50.14 \%$ ), respectively. Young rattan phase $(3 \mathrm{~m}-5 \mathrm{~m})$ it was dominated by $P$. elongata (IVI $=116.81 \%)$ followed by $D$. melanochaetes $($ IVI $=82.01 \%)$, and $C$. heteroideus $($ IVI $=38.08 \%)$ respectively. At the old rattan phase, it was dominated by $P$. elongata (IVI $=103.16 \%)$, followed by $D$. ruber (IVI $=78.19 \%)$ and C. ornatus (IVI $=51.95 \%)$ respectively. 
At Mt. Pameungpeuk for regeneration phase, it was dominated by C. beteroideus (IVI $=65.55 \%$ ), followed by $C$. javensis and D. melanochaetes, with IVI $=51.16 \%$ and $21.97 \%$ respectively. At the young rattan phase it was dominated by $C$. javensis (IVI $=107.71 \%$ ) followed by $P$. elongata (IVI $=89.41 \%$ ) and $C$. beteroideus. For adult rattan phase, it was dominated by $C$. javensis (IVI $=$ $142.65 \%$ ), followed by $K$. jungbubnii (IVI $=32.12 \%$ ) and C. melanoloma (IVI $=30.74 \%)$. For old rattan phase, it was dominated by $P$. elongata (IVI $=108.43 \%$ ), followed by $C$. javensis (IVI $=$ $80.08 \%$ ) and $K$. junghubnii (IVI $=66.15 \%$ ). The related data were presented in Table 6 .

Table 6. Importance Value Index (IVI) of rattan species in Mt. Pameungpeuk

\begin{tabular}{|r|l|c|c|c|c|}
\hline \multirow{2}{*}{ No } & \multicolumn{1}{|c|}{ Species } & \multicolumn{4}{|c|}{ IVI (\%) } \\
\cline { 3 - 6 } & & Seedling & Young rattan & Adult rattan & Old rattan \\
\hline 1 & C. heteroideus & 65.55 & 55.70 & 16.30 & 0.00 \\
2 & C. javensis & 51.16 & 107.71 & 142.65 & 80.08 \\
3 & D. melanochaetes & 21.97 & 9.29 & 19.45 & 0.00 \\
4 & D. oblonga & 12.94 & 6.42 & 8.77 & 0.00 \\
5 & P. elongata & 10.08 & 89.41 & 13.43 & 108.43 \\
6 & D. bystrix & 8.88 & 3.07 & 3.19 & 0.00 \\
7 & C. ciliaris & 7.72 & 13.06 & 5.56 & 0.00 \\
8 & C. asperrimus & 5.41 & 0.00 & 4.40 & 24.57 \\
9 & K. jungbubnii & 4.13 & 3.07 & 32.12 & 66.15 \\
10 & D. ruber & 3.26 & 3.07 & 8.72 & 0.00 \\
11 & C. rhomboideus & 1.53 & 0.00 & 0.00 & 5.95 \\
12 & C. melanoloma & 0.98 & 14.21 & 30.74 & 20.76 \\
13 & C. ornatus & 0.52 & 0.00 & 8.72 & 0.00 \\
\hline
\end{tabular}

At Mt. Pangkulahan it showed that at regeneration phase was dominated by $C$. heteroideus (IVI $=75.97 \%$ ) then followed by C. javensis (IVI $=32.34 \%$ ) and D. melanochaetes (IVI $=26.70 \%$ ). For young rattan phase and adult rattan phase, only one rattan species could be found, i.e. C. javensis. Meanwhile for old rattan phase, in fact none of the rattan species could be found. The related data were presented in Table 7.

Table 7. Importance Value Index (IVI) of rattan species in Mt. Pangkulahan

\begin{tabular}{|r|l|c|c|c|c|}
\hline \multirow{2}{*}{ No } & \multirow{2}{*}{ Species } & \multicolumn{4}{|c|}{ IVI (\%) } \\
\cline { 3 - 6 } & & Seedling & Young rattan & Adult rattan & Old rattan \\
\hline 1 & C. beteroidus & 75.97 & 0.00 & 0.00 & 0.00 \\
2 & C. javensis & 32.34 & 300.00 & 0.00 & 0.00 \\
3 & D. melanochaetes & 26.70 & 0.00 & 0.00 & 0.00 \\
4 & C. ciliaris & 24.45 & 0.00 & 0.00 & 0.00 \\
5 & P. elongata & 21.33 & 0.00 & 0.00 & 0.00 \\
6 & D. oblonga & 8.68 & 0.00 & 0.00 & 0.00 \\
7 & D. ruber & 8.68 & 0.00 & 0.00 & 0.00 \\
8 & C. ornatus & 1.48 & 0.00 & 0.00 & 0.00 \\
9 & C. rhomboideus & 1.04 & 0.00 & 0.00 & 0.00 \\
10 & K. jungbubnii & 0.99 & 0.00 & 0.00 & 0.00 \\
11 & C. melanoloma & 0.48 & 0.00 & 0.00 & 0.00 \\
12 & C. asperrimus & 0.18 & 0.00 & 0.00 & 0.00 \\
\hline
\end{tabular}




\section{CONCLUSION AND RECOMMENDATION}

\section{A. Conclusion}

1. In Mt. Kancana, Mt. Pameungpeuk, and Mt. Pangkulahan, GHNP, there were found as many as 13 rattan species, i.e. C. asperrimus, C. beteroideus, $C$. ciliaris, $C$. javensis, $C$. melanoloma, C. ornatus, C. rhomboideus, D. bystrix, D. oblonga, D. ruber, K. junghubnii, P. elongata and $D$. melanochaetes.

2. The rattan in Mt. Kancana, Mt. Pameungpeuk, and Mt. Pangkulahan, represented as many as $80 \%$ of Genus and $72.2 \%$ of species of all the rattan species available in West Java.

3. The rattan population density of the whole species in Mt. Kancana, Mt. Pameungpeuk and Mt. Pangkulahan were: $649.00 ; 1798.79$; and 1493.25 stems/ha respectively.

4. Most of the rattan species in Mt. Kancana, Mt. Pameungpeuk and Mt. Pangkulahan at the GHNP belonged to stem diameter class $<0.5 \mathrm{~cm}$. Rattan density were decreasing parallel with the increasing of stem diameter class. Rattans with moderate, big and super size were only found in a very few quantity.

5. Thirteen rattan species in the three mount areas in Gunung Halimun National Park were spread at the altitude of $800-1050 \mathrm{~m}$ asl. Further at the altitude of $1050-1250 \mathrm{~m}$ asl., the number of rattan species were decreasing to 11 species and to 6 species at the altitude of $1250 \mathrm{~m}$ asl.

6. Important Value Index (IVI) from seedling phase to old rattan phase in Mt. Kencana was dominated by P. elongata, D. melanochaetes and C. heteroideus. Meanwhile, in Mt. Pameungpeuk it was dominated by $C$. javensis, $P$. elongata and $C$. heteroideus and in Mt. Pangkulahan, by $D$. melanochaetes. The rattan regeneration in Mt. Pangkulahan was discontinued, because no rattan species could be found at old age.

\section{B. Recommendation}

Considering the result of the research mentioned above, it is expected that the maintenance of Gunung Halimun National Park has to be increased. Providing the buffer area between the forest and villages or estate plantation is appreciated.

\section{REFERENCES}

Dransfield, J. 1974. A Short Guide to Rattans. Biotrop/TF/74/128, Bogor, Indonesia. 69 pp. Dransfield, J. 1979. A Manual of Rattans of The Malay Peninsula. Malayan Forest Record No. 29. Forest Record No. 29. Forest Department Ministry of Primary Industries Malaysia. 254 pp. 
Dransfield, J, J.P. Mogea and Manokaran. 1989. Rattan. Proceeding of the PROSEA International Symposium. Jakarta : Pudoc Wageningen. pp. $130-141$.

Hadi, D. W. 1994. Keanekaragaman Floristik Taman Nasional Gunung Halimun dan Pemanfaatan oleh Masyarakat Sekitar. 177 pp.

Intag. 1989. Pedoman Inventarisasi Rotan. Direktorat Inventarisasi Hutan Departemen Kehutanan. $55 \mathrm{pp}$.

Istiadi, Y, B. Ryadhisoetrisno, I. Kurniawan, Y. Novendri, Azwar, T. Hartono, Rudy, N. Lubis. 1991. Keanekaragaman Hayati Cagar Alam Gunung Halimun. Biological Science Club. 140 pp.

Jacobs. M. 1981. The Tropical Rain Forest. A First Encounter, Berlin Heidelberg New York, London Paris Tokyo. pp. 1- 3.

Kramadibrata, P. 1992. A revision of the Genus Calamus (Palmae) section Macropodus sensu Furtado. Thesis for the degree of Doctor of Philosophy. Departement of Biology University of Reading. 245 pp.

Lembaga Penelitian Tanah. 1996. Peta Tanah Tinjau Jawa Barat. LPT. Bogor. Madulid, D. E. 1981. Revision of genus Plectocomia (Palmae:Lepidocaryoidea). Kalisan, The Philppine Journal of Biology 10. University of the Philppines at Los Banos College, Laguna. $93 \mathrm{pp}$.

Mueller-Dumbois, D, and H. Ellenberg. 1974. Aims and Methods of Vegetation Ecology, John Wiley and Sons. New London. Sydney Toronto.

Rombe, Y.L. 1986. Inventarisasi Potensi Rotan Indonesia. Prosiding Lokakarya Nasional Rotan Departemen Kehutanan. pp. 1 - 10.

Perlindungan Hutan dan Pelestarian Alam (PHPA). 1992. Pegunungan di bawah garis pelangi Taman Nasional Gunung Halimun. Direktorat Jendral Perlindungan Hutan dan Pelestarian Alam. Cipanas-Cianjur, Jawa Barat

Pratiwi. 1987. Analisis komposisi jenis pohon di Taman Nasional Gunung Gede Pangrango, Jawa Barat. Buletin Penelitian Hutan, Pusat Penelitian dan Pengembangan Hutan, Bogor. pp. 2834.

Schmidt, F.H. and J.H.A Ferguson. 1951. Rainfall Types Based on Wet and Dry Period Rations for Indonesia with Western New Guinea. Kementrian Perhubungan Jawatan Meteorologi dan Geofisik, Republik Indonesia, Jakarta.

Setyawati, T. 1995. Physiognomy of Forest Vegetation on Mount Gede Pangrango, West Java Indonesia. Thesis for degree of Master of Science of Forestry, Missisipi University, USA. $90 \mathrm{pp}$.

Siswanto, B.E. 1991. Metode Inventarisasi Rotan di Kelompok hutan sungai Aya Hulu Sungai Kalimantan Selatan. Buletin Penelitian Hutan. Pusat Penelitian dan Pengembangan Hutan dan Konservasi Alam. pp. 13 - 22.

Soerianegara, I and A. Indrawan. 1988. Ekologi Hutan Indonesia. Departemen Manajemen Hutan Fakultas Kehutanan, IPB, 123 pp.

Steenis, C.G.G.J. van . 1972. The Mountain Flora of Java. E.J. Brill. Leiden. 80 pp. Sutarno, H., R.E. Nasution dan J.P. Mogea. 1994. Rotan : Pendayagunaan Lahan Marginal dan Pelestarian Jenisnya. Prosea 6.2. Prosea Indonesia Bogor. 34 pp.

Uhl, $\mathrm{N}$ and J. Drasfield. 1987. Genera Palmarum A Classification of Palms. The L.H. Bailey Hortorium and The International Palm Society. $478 \mathrm{pp}$.

World Conservation Monitoring Center (WCMC). 1992. Global Biodiversity. Brian Groombrige (ed). Chapman and Hill, London 350 pp. 